\title{
Analysis of Understanding the Concept Using Assignment Techniques on Students' Learning Interest in Irsyadul Islamah Mass PP
}

\author{
Rina $^{1}$, Eva Julyanti ${ }^{2}$ \\ ${ }^{I}$ Faculty of Teacher Training and Education Universitas Labuhanbatu, Indonesia \\ rinar4355@gmail.com,evajulianti.26@gmail.com
}

\begin{abstract}
This study aims to analyze conceptual understanding and increase student interest in learning by using assignment techniques in the form of material and SPLDV questions and also an assessment questionnaire. This research uses descriptive qualitative research methods. The subjects who were the research targets were class VIII in MASS PP IRSYADUL ISLAMAH totaling 35 students. The research instrument used was an assignment questionnaire and an interest in learning outcomes. The material is used to provide understanding of the assignment and see the students' interest in learning the assessment subject. Seeing the interest in learning in student assignment techniques in solving problems with SPDLV Mathematics learning questions, students were given an assessment questionnaire on how the teacher applied Mathematics learning. The results of this study indicate that there is an increase in student interest in learning, The increase in research resulted in 11 highest numbers of learning interest, 21 moderate numbers and 3 were in the lowest numbers in student interest in learning. From the results of this study the researchers succeeded in suppressing the lowest number and increasing the highest number of students' understanding and interest in solving problems in learning mathematics. The results of the student's interest in learning obtained an increase in interest in learning by $6.58 \%$ in MASS PP IRSYADUL ISLAMAH.
\end{abstract}

\section{Keywords}

assignment techniques, learning interests, concept understanding

\section{Introduction}

In Indonesia, education is quite large in preparing the bagsa generation, in the world of education, especially in addressing their mentality in the times. However, in Indonesia it has quite a large influence. Ainsyiyah (2020) stated that good quality education can occur through a variety of factors that are related to planning, process, community support, and facilities in schools. Therefore, the government pays more attention to education in Indonesia at the elementary, junior high and high school levels, education which has a big influence, especially on learning mathematics. Because learning mathematics is very important to be applied to the real world. Mathematics is knowledge, thought, learning and science that studies quantity, structure, space, and change.

Supartono agrees with this pointing out that "the fact that is often encountered is that there are still many students who experience difficulties in learning mathematics" (Misdalina, 2009: 62). So that the average result of learning mathematics is always the smallest compared to other subjects(Sheilla Rosalline, Mailizar2 2019). According to supinah's opinion (Toyyibah and Setyawan nd) analysis of learning mathematics can first identify problems related to student life, then students are guided to master mathematical 
concepts with an active role in learning. Then a learning activity is made, giving students the opportunity to understand the material being studied and can change behavior patterns in these students.(Vellayati 2017).

Therefore it is necessary to apply conceptual understanding for students in learning mathematics so that students are not just learning but students understand the material presented by the teacher, with a mature understanding, students can solve a problem and be able to apply this learning to the real world. So in understanding the concept, you must use assignment techniques, in this case they will be easy to understand formulas and problems or Mathematics lessons, so it will be easy to apply them in the real world. After students understand the conceptual understanding in mathematics, there are no more students who find it difficult to learn mathematics.

To apply conceptual understanding in mathematics learning using assignment techniques, the assignment technique is a teaching and learning process by giving assignments to students, the tasks are in the form of story problems, multiplication, addition, division and subtraction. Assignment techniques are assumed to be a solution to problems with student interest in learning where the assignment technique is to assign assignments to students to generate student interest in learning. This assignment technique is very suitable to be given to students for mathematics learning materials in understanding students' learning interests. Pupuh Fathurrohman (2010, p. 64). The method of assignment is not the same as homework, but it is much broader than that. There are various types of tasks that can be given to students, because of that, there are many kinds of tasks,

The purpose of education is to increase students' interest in learning with knowledge, it is intended that learning is made more understanding of what they have done in everyday life, and it is hoped that students can understand their own knowledge, which is not limited to memorizing which allows students to forget the material that has been learned in the previous class(Gazali and Atsnan 2017). Through training on the basis of thinking logically, rationally, critically, carefully, honestly, efficiently and effectively(Chrissanti and Widjajanti 2015). Education is one way to produce quality Human Resources (HR) with experience changes in knowledge, skills and attitudes. These changes can be a capital to improve selfcompetence in facing the era of globalization that always undergo the change (Sitorus et al, 2019).

The solution of assignment techniques in learning interest is by giving assignments in the form of stories with formulas, exercises, communicating ideas with symbols, tables, or diagrams or other media with the solution aimed at secondary education is to increase student interest in learning with knowledge, through practice acting on the basis of thinking logically, rationally, critically, carefully, honestly, efficiently and effectively (Chrissanti and Widjajanti 2015). The research objective is based on the techniques used to determine students 'interest in learning towards Mathematics subjects according to predetermined school levels, after knowing the students' interest in learning about these subjects can find ways and solutions for how to increase student interest in learning and to make it easier for students to learn and understand Mathematics in school.

Based on these objectives, it is necessary to apply conceptual understanding, understanding mathematical concepts is the most basic thing in learning mathematics. Understanding the concept is also a cognitive aspect which is one of the goals of learning mathematics. By understanding mathematical ideas that are thorough and functional. Therefore, understanding concepts is a fundamental part of building mathematical knowledge. Students are able to understand mathematical concepts by: (1) expressing the concept in their own words; (2) identify and provide examples or not examples of 
concepts; (3) applying / using the concept correctly in various situations(Pratiwi, Astawa, and Mahayukti 2019).

Therefore, understanding the concept can increase students' interest in learning. interest is something that is preferred or preferred in certain work activities. Student interest in learning is something that is preferred in learning activities, so in this case without interest in learning mathematics, understanding of mathematical concepts will not be achieved. Based on the title above, it can be concluded that the researcher wants to improve and understand students 'interest in learning Mathematics by means of the concept of assignment, in order to see students' interest in learning and like Mathematics, with the conclusion that the researcher has obtained, the researcher makes the title in this study is "Analysis understanding the concept of using assignment techniques to students' interest in learning class VIII in MASS PP IRSYADUL ISLAMAH".

\section{Review of Literature}

\subsection{Understanding the Concept}

Understanding the concept based on the title above is analyzing conceptual understanding by giving assignments or questions and formulas in the form of numbers, addition, subtraction, multiplication, division and the like to see and increase student interest in learning, with the concept of assignment strived so that students can understand the material in the form of formulas and questions so that students do not experience difficulties in understanding mathematical material, with a mature understanding, students can solve problems and be able to apply the learning to the real world(Komariyah, Afifah, and Resbiantoro 2018) Indicators of conceptual understanding according to the 2006 KTSP (education unit level curriculum) include:

1. Restate a concept.

2. Clarifying objects according to certain properties (according to the concept).

3. Provide examples and non-examples of concepts.

4. Presenting concepts in various forms of mathematical representations.

5. Develop a necessary or sufficient condition of a concept.

6. Using, utilizing, and selecting specific procedures or operations.

7. Apply a problem-solving concept or algorithm.

\subsection{Engineering Assignment}

The assignment technique is carried out by providing a test sheet in the form of questions and a questionnaire in the form of writing opinions on student learning interests. The test sheet is given to students, the test sheet aims for students to increase their interest in learning and understand formulas and questions in the form of numbers and stories on Mathematics lessons, because what students are expected to understand is each Mathematics subject matter so that students do not experience difficulties later when given material in the form of formulation and question assignments to students. The questionnaire is where writing is used to assess students' learning interest in the material and questions given, with the teacher's questionnaire for students in order to measure students' learning abilities and interests, after measuring students' understanding and interest in learning. According to Argareta Simorangkir (2018) one of the efforts to improve the ability of student number sense is that teachers should be able to create an interesting and enjoyable learning atmosphere by using technology as a learning medium. Media is a learning aid that can act as a channel for information directly or indirectly in the learning process. 


\subsection{Interest to Learn}

Interest in learning mathematics, namely as the involvement of students and themselves in full carrying out mathematics learning activities both at home and at school and in the community. students who have an interest in learning mathematics have the desire and effort to achieve mathematics learning (Narendrati 2017). This is what encourages students in their interest in learning about material understanding and math problems is very important, with motivation and interest in spurring student enthusiasm to learn and understand, student motivation is one of the internal factors that affect student interest in learning. (Hemayanti, Muderawan, and Happy 2020). that is the reason why interest in learning is prioritized and enhanced for students, because interest means like it if students already like and understand the subject, especially mathematics. With interest or liking these lessons, students' enthusiasm arises to understand Mathematics.

The characteristics of the interest section are having a constant tendency to pay attention and remember something continuously, in the sense that students who have an interest in learning tend to pay attention to the teacher when teaching and when students do not understand and understand, with interest in learning students will continue to pay attention to understanding and understand, even to continue to think to understand what parts are not yet understood. Furthermore, obtaining pride and satisfaction with the things they are interested in means that students will be proud if they can understand the subject they are interested in without feeling difficult anymore, especially Mathematics which is known to be difficult to understand, if students can understand and understand then they will be proud and self-satisfied. arises in themselves because of high interest in learning. The last is participation in learning, and interest in learning is influenced by culture, in the sense that each student's learning process participates in learning, because of high learning interest students have a strong desire to take part in learning at school even at home students can repeat lessons at school, but the current learning culture of many students lack of interest in learning, a culture that rarely repeats lessons in school,

Supriatna(Komariyah, Afifah, and Resbiantoro 2018). There are several indicators of interest that are known or can be seen through the learning process, including the following:

1. An interest in reading books.

Students who are interested in a lesson will have a feeling of interest in learning. Students who are interested in the field of Islamic religious education will feel interested in studying it. He will study diligently and continue to study all the sciences related to these subjects, he will follow the lessons enthusiastically without any burden on him.

2. Attention in learning.

Attention is the concentration or activity of a person's soul on observation, understanding or anything else, with the exclusion of other things. So, students will have attention in learning, their souls and minds are focused on what they are learning.

3. Student activeness in learning mathematics.

Someone can express interest not through words but through actions or deeds, participate actively in a certain activity. So if a student has an interest in mathematics, the student will play an active role when learning mathematics.

4. Knowledge.

Apart from feelings of pleasure and attention, to find out whether a student is interested or not in a lesson can be seen from the knowledge he has. Students who are interested in a lesson will have extensive knowledge about the lesson and how the benefits of learning in everyday life. 


\subsection{Solution to Problem}

In general, the reference for solving mathematical problems goes to the book How to solve it (1973) which has four stages, (1) understanding the problem, (2) planning problem solving, (3) implementing the solution plan, and (4) checking again.(Riskayani, Werdhiana, and Hatibe 2017). The problems that occur and are discussed in research are a problem in terms of junior high school student learning interest, lower learning interest, making students difficult to understand and understand and even hate lessons, especially mathematics, not a few junior high school students when given assignments at school or at home are not done because students do not have the desire to do, the factor is there is no desire because they do not understand and understand the material and questions, and do not understand or understand the material and questions because of the low learning interest of students to learn from these subjects, namely Mathematics.

And currently the reason for the low interest in student learning is because of (modern) culture, culture is very influential on student interest in learning, current culture, namely modern or technology, makes students play more technology (cellphones) than learning, plus the learning process of students who use technology makes it easier to find what is not known from the material or questions, there is no learning through hard training like the old culture, namely one example of calculating manually or memorizing.

Saad \& Ghani (Komariyah, Afifah, and Resbiantoro 2018), states that problem solving is a planned process that needs to be carried out in order to obtain a certain solution of a problem that may not be obtained immediately. To solve the above problems, an assignment technique is used. The assignment technique was chosen because it was to increase or train students' interest in learning and student understanding, with the assignment technique in the form of giving test sheets and questionnaires to students who could see the level of interest in student learning individually.

In this case, students are given an interest in learning questionnaire which is then classified into students who have high, medium and low learning interest. In this study, 6 students took the subject to represent the division of student interest groups. The flow in this research starts from selecting the class used as the subject, then conducting a learning interest questionnaire test for grouping students who have high, medium, and low interest in learning. Researchers give tests of math problems after the subjects are categorized into high, medium, and low interest. Then the researcher conducted interviews with the subject. To test the credibility of this study using time triangulation, the researcher then analyzed the data and ended this study by writing a research report.

\section{Research Methods}

The research objective is to analyze the limits of student interest in learning, after analyzing student interest in learning, it can increase student interest in learning so that they are motivated and understand the material and questions in each learning process, with this purpose it can be applied to students, and students who are having difficulty understanding so that increased interest in learning from students

This research is a qualitative research that uses the classroom action method where the classroom action method in this study is carried out to increase the interest in learning in the MAS PP IRSYADUL ISLAMIA school which is aimed at class VIII.

According to Sugiyono said that qualitative is wanting to describe the reality behind a phenomenon in depth, detail and thoroughly. This means that the data collected is not in the form of figures, but the data comes from agket and observations that have been made. 


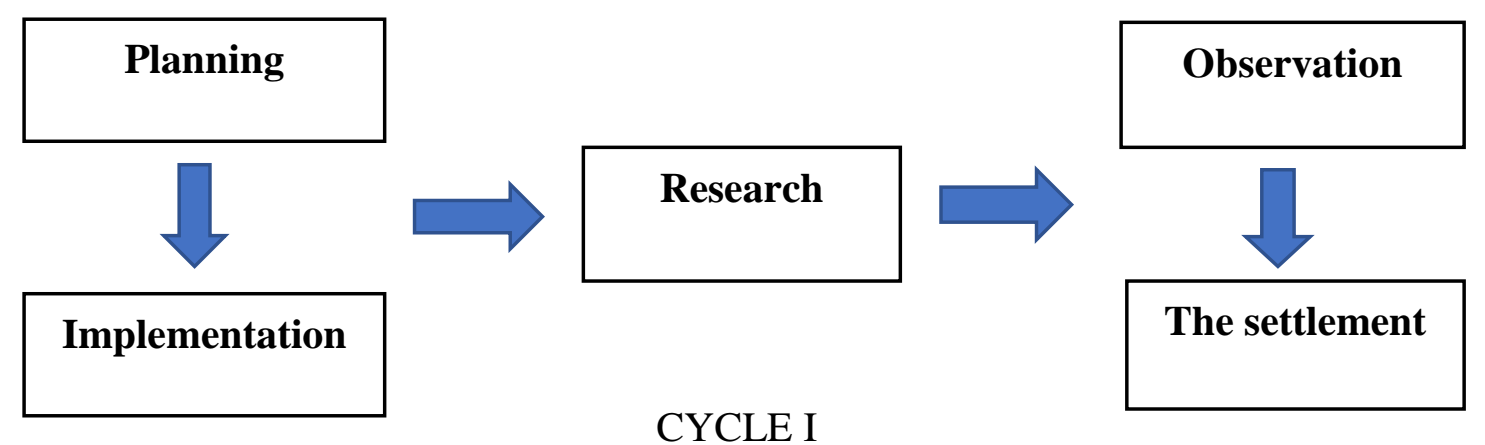

As for the place and time of research, the research was carried out at MASS PP IRSYADUL ISLAMAH, sub-district of the people's village, labuhanbatu selatan district. The reason for researching in this place is because researchers see the low interest in students' learning towards mathematics. Together with the place of time of this research during the months of February 2021 - March 2021.

The subjects of this study were students of class VIII, this study had two sources of data, namely primary and secondary data, primary was aimed at secondary students of teachers. Primary data is data made by research for the specific purpose of solving the problem at hand. The data is collected by the researcher directly from the first source or the place where the research object was carried out. Secondary data is data that has been collected for purposes other than solving the problem at hand.

The tools that will be used to collect data, this research instrument can be in the form of questionnaires, observation forms, other forms related to data recording and so on. The instruments used in this study were (1) an interest in learning questionnaire sheet that was made to determine the achievement of the learning process carried out by students in mathematics lessons. (2) Observation sheet. The observation sheet that was made was to determine the activities carried out by the teacher and students when carrying out the assignment method using the observation sheet format.

\section{Results and Discussion}

The research was carried out using several methods, the first was explaining the material SPLDV (Two Variable Linear Equation System), which started by explaining the meaning of SPLDV, SPLDV, which is having a system of equations or the same form of relation in algebraic form which has 2 variables and a power of 1 and if it is depicted in a graph it will be in the form of a straight line, then this equation is called a linear equation, then it explains the sub-sub of SPLDV, namely terms, variables, coefficients and constants, and the last one explains the SPLDV solution method, namely by the first 4 methods the substitution method, the elimination method, the combined method (substitution and elimination), and the graph method, however, in this study, the graphical method is more used, so the graphical method is described in more depth.

That second, give examples and practice questions, the questions given remain on the material used, namely 1 sample question and 10 practice questions. The third day on the agenda was giving a questionnaire. The questionnaire given contains the statements of students towards the teacher in the application of Mathematics learning once aimed at seeing students' interest in learning Mathematics. The questionnaire given consists of 20 statements. 
In the results of this study the selection of grouping interest in learning subjects categorized into subjects having high, medium and low interest.

Table 1. Criteria for Classification of Learning Interest

\begin{tabular}{|c|c|}
\hline Criteria Grouping & Category \\
\hline Value $>$ mean + SMP & High \\
\hline Mean - SMP < value <mean + SMP & Moderate \\
\hline Value <mean + junior high school & Low \\
\hline
\end{tabular}

Researchers grouped the subjects after calculating the value obtained from the interest in learning questionnaire test. The following is table 2 of the results of subject grouping based on a student learning interest questionnaire, including the following:

Table 2. Table of Results for Grouping Learning Interests

\begin{tabular}{|c|c|c|}
\hline NO & Name & Interest Category in Learning \\
\hline 1 & AND & High \\
\hline 2 & BPP & High \\
\hline 3 & HDN & High \\
\hline 4 & MAS & High \\
\hline 5 & NN & High \\
\hline 6 & RIP & High \\
\hline 7 & RP & High \\
\hline 8 & SN & High \\
\hline 9 & SA & High \\
\hline 10 & DH & High \\
\hline 11 & IAI & High \\
\hline 12 & RA & Moderate \\
\hline 13 & SF & Moderate \\
\hline 14 & MAF & Moderate \\
\hline 15 & $\mathrm{IH}$ & Moderate \\
\hline 16 & AR & Moderate \\
\hline 17 & SCR & Moderate \\
\hline 18 & SRR & Moderate \\
\hline 19 & $\mathrm{FH}$ & Moderate \\
\hline 20 & OPN & Moderate \\
\hline 21 & NS & Moderate \\
\hline 22 & $\mathrm{NF}$ & Moderate \\
\hline 23 & MRN & Moderate \\
\hline 24 & MBR & Moderate \\
\hline 25 & MS & Moderate \\
\hline 26 & IM & Moderate \\
\hline 27 & $\mathrm{HE}$ & Moderate \\
\hline 28 & ICE & Moderate \\
\hline 29 & DS & Moderate \\
\hline 30 & BS & Moderate \\
\hline 31 & ALA & Moderate \\
\hline 32 & ADR & Moderate \\
\hline 33 & LS & Low \\
\hline 34 & $\mathrm{RH}$ & Low \\
\hline 35 & APL & Low \\
\hline
\end{tabular}


Based on table 2, the results for students 'interest in learning towards mathematics learning, that students' interest in learning increases by using the understanding of the concept of assignment techniques, it can be seen from table 2 that of the 35 specified subjects, only 3 students are at the lowest level of understanding, 21 students are at a moderate level in comprehension, and 11 students were at the highest level of understanding the applied task technique. With the assignment technique used by researchers, it has succeeded in increasing students' understanding and interest in learning, which can be a reference for teachers to students in schools.

And the researcher also got the results of the research seen from the character of the students, namely the students' interest in learning would certainly affect the understanding of concepts in solving problems. From the data that the researchers obtained, that subjects with high interest in learning tended to have superior understanding of concepts in problem solving. Subjects who have a high learning interest are wiser in solving problems in each Mathematics lesson, subjects with high learning interest explain what is known to be close to perfection in understanding during the learning process, ask questions if they do not understand, make planning strategies for solving problems faced by Mathematics lessons and carry out the strategies made to solve Math problems,

Subjects with moderate learning interest can understand the problem well, the subject can explain only what is known and ask questions in the problem. After knowing and understanding the subject, immediately implement a strategy with a concept that is only remembered. However, when implementing the problem-solving strategy the subject does the concept that is not quite right. But with the problem solving strategy used, the subject still gets the correct answers and results, in the sense that subjects with moderate learning interest can or are able to understand and explain but have not been able to link between questions, and are not sure of the concept.

And subjects with low learning interest can still understand and explain, and also ask questions on problems, but the subject stops at the advanced stage of implementing problem-solving strategies, because the subject has difficulty and is confused in implementing strategies in problem solving. So that the subject stops when planning strategies, and that makes the subject unable to solve problems in Mathematics learning.

\section{Conclusion}

Research that aims to analyze conceptual understanding in order to see students' learning abilities and interest in Mathematics learning by way of assignment techniques to students, research using assignment techniques, namely by direct research to IRSYADUL MTS students by providing SPLDV material, examples of SPLDV questions, questions SPLDV exercises given to students to complete and student assessment questionnaires to teachers.

With the research assignment techniques to students to determine students' learning abilities and interests. And from the research results found, the researcher found students' interest in learning at various levels, from the highest level, the medium level and the lowest level. While for the highest level can explain the concept or learning material of Mathematics and question what the subject does not know, then the highest level subject can plan strategies, implement and solve Mathematics learning problems correctly. The medium level subject is also almost the same as the highest level, it's just that the medium level subject is not quite right in doing the concept with the strategy that has been made even though the results and answers are correct. Whereas the lowest level can explain what is known only, and ask questions on problems 


\section{References}

Ainsyiyah, E.D., et al. (2020). Pancasila and Civic Education Learning by Non Pancasila and Civic Education Program Graduate. Budapest International Research and Critics Institute-Journal (BIRCI-Journal). P. 1650-1659.

Argareta Simorangkir, F.M., et al. (2018). Effectiveness of Helped Mathematical Learning Media of Lectora Inspire on The Number Sense Ability of Fifth Grade Students of Elementary School in Substrate Materials. Budapest International Research and Critics Institute-Journal (BIRCI-Journal). P. 352-358.

Chrissanti, Maria Isabella, and Djamilah Bondan Widjajanti. 2015. "Keefektifan Pendekatan Metakognitif Ditinjau Dari Prestasi Belajar, Kemampuan Berpikir Kritis, Dan Minat Belajar Matematika.” Jurnal Riset Pendidikan Matematika 2(1): 51.

Gazali, Rahmita Yuliana, and Muh Fajaruddin Atsnan. 2017. "Peningkatan Motivasi Dan Minat Belajar Matematika Siswa Melalui Pendekatan Kontekstual Dalam Pembelajaran Matematika Yang Bermakna." Pythagoras: Jurnal Pendidikan Matematika 12(2): 123-34.

Hemayanti, Ketut Lia, I Wayan Muderawan, and I Nyoman Selamat. 2020. "Analisis Minat Belajar Siswa Kelas Xi Mia Pada Mata Pelajaran Kimia.” Jurnal Pendidikan Kimia Indonesia 4(1): 20.

Komariyah, Siti, Dian Septi Nur Afifah, and Gaguk Resbiantoro. 2018. "Analisis Pemahaman Konsep Dalam Memecahkan Masalah Matematika Ditinjau Dari Minat Belajar Siswa." SOSIOHUMANIORA: Jurnal Ilmiah Ilmu Sosial dan Humaniora 4(1): 1-8.

Narendrati, Nevi. 2017. "Komparasi Pembelajaran Statistika Melalui Pendekatan CTL Dan Problem Posing Ditinjau Dari Prestasi Belajar Dan Minat Belajar Matematika." Jurnal Riset Pendidikan Matematika 4(1): 67.

Pratiwi, Ni Pande Kadek Ayu, I Wayan Puja Astawa, and Gusti Ayu Mahayukti. 2019. "Missouri Mathematics Project (MMP), Pemahaman Konsep Matematika, Dan Kepercayaan Diri Siswa.” Jurnal Elemen 5(2): 178.

Riskayani, Riskayani, I Komang Werdhiana, and Amiruddin Hatibe. 2017. "Penerapan Problem Solving Menggunakan Strategi Heuristik Terhadap Pemahaman Konsep Tentang Kalor Pada Siswa Kelas X SMA Negeri 4 Palu.” JPFT (Jurnal Pendidikan Fisika Tadulako Online) 5(2): 25.

Sheilla Rosalline, Mailizar2, \& Lasia Agustina. 2019. "Pengaruh Model Pembelajaran CORE ( Connection, Organizing, Reflecting, Extending ) Terhadap Pemahaman Konsep Matematika Siswa Suatu Bangsa , Karena Pendidikan Merupakan Sarana Untuk Meningkatkan Dan Mengembangkan Kualitas Pemerintah . Pendidikan Formal.” JKPM (Jurnal Kajian Pendidikan Matematika) 2682(1): 1-10.

Sitorus, H.V., et al (2019). The Effect of Learning Strategy and Thinking Ability on The Students' Learning Outcomes in Economics Subject of XI Social Students in Senior High School State 1 in Pematang Siantar. Budapest International Research and Critics in Linguistics and Education (BirLE) Journal. P. 451-460.

Toyyibah, Nur, and Agung Setyawan. "Analisis Pemahaman Matematika Terhadap Hasil Belajar Siswa Kelas II SDN Bancaran 4 Bangkalan.” : 288-94.

Vellayati, Susti. 2017. "Analisis Aktivitas Belajar Siswa Dan Aktivitas Pembelajaran Guru Pada Mata Pelajaran Kimia (Studi Kasus Di SMA Negeri 8 Banda Aceh Tahun 2016/2017)." Seminar Nasional Mipa Iii: 119-26. 